\title{
CONCENTRATION OF SOME AMINO ACIDS IN BLOOD PLASMA AND STUDY RESULTS OF LUMBOSACRAL BONE SYSTEM COMPUTER TOMOGRAPHY
}

\author{
Gustaw Wójcik ${ }^{1,2}$, Barbara Sokołowska³ ${ }^{\text {, Andrzej Borzęcki }}{ }^{3}$ \\ ${ }^{1}$ Department of Balneotherapy, Chair of Rehabilitation, \\ Physiotherapy and Balneotherapy, Medical University of Lublin \\ ${ }^{2}$ Department of Imaging Diagnosis, Zofia Tarnowska from the Zamoyskis Provincial Hospital in Tarnobrzeg \\ ${ }^{3}$ Department of Health, Pope John Paul II State School of Higher Education in Biała Podlaska
}

Wójcik G., Sokołowska B., Borzęcki A. (2015), Concentration of some amino acids in blood plasma and study results of lumbosacral bone system computer tomography. Health Problems of Civilization, 3 (9), p. 5-11.

\begin{abstract}
Summary: Introduction and objective: Back pain are the most common ailment within the human locomotor system. Because of their prevalence, they were classified as diseases of civilization. The aim of the study was to attempt to assess the concentration of selected amino acids in plasma and correlating the results of laboratory tests with the occurrence of backaches.

Material and method: The study group included 188 patients presenting for CT scan administering as the cause of their symptoms low back pains. All of these patients gave the blood samples from which the concentration of free amino acids was estimated by ion exchange chromatography using an automated amino acid analyzer AAA 400 from INGOS Praha. The control group consisted of patients who underwent testing using computed tomography and there were no primary or secondary changes associated with degeneration in the lumbar spine.

Results: Patients on the basis of research carried out by computed tomography were divided into five groups according to disease entity. Analyzing the average concentration of essential amino acids in the blood plasma of patients of each group, it was found that it is higher in the case of lysine for each considered disease entity. The average concentration of methionine in all disease entities does not deviate from the average values in the control group. Analysis of the average concentration of selected essential amino acids revealed that in the case presented disorders underwent their level of variation. Average concentrations of selected amino acids have proven to be very similar in both groups. Slightly higher values proved to be in the control group for proline and lysine.

Conclusions: The concentration of amino acids varies with the severity of degenerative changes in the connections as well as in interbody joints. The highest increase in the concentrations of all tested amino acids are present in root bands. Decrease in the concentrations of all tested amino acids appears in cancer.
\end{abstract}

Keywords: amino acids, chromatography, computed tomography, lumbar spine

\section{Introduction}

The structural changes of spine are closely linked to the aging of the organism, however, overloads to which is the lumbar spine is subjected will accelerate the rate of degenerative changes, resulting in faster formation of pathology (Ciejka, Wójtowicz 2009). The man using the benefits of civilization and technological progress wants to live more comfortably, and in turn this has a negative impact on the entire musculoskeletal system, its weakening leading to irreversible structural changes known as degenerative joint disease (Jens Ivar Brox et al. 2008, Borenstein 2013).

Back ache in the lumbar-sacral part apply each year to about half of the adult population in the world (Borenstein 2013). Epidemiological studies have shown that over 50\% of elderly people suffer from low back pain. According to many authors, lower back pain is the most common cause of absence from work of people under 45 years of age (Jens Ivar Brox et al. 2008).

Computed tomography is an indirect method of obtaining an image of the examined parts of the musculoskeletal system. This allows for imaging of both bone structures, as well as muscular and ligament

\footnotetext{
Address for correspondence: Gustaw Wójcik, Department of Imaging Diagnosis, Zofia Tarnowska from the Zamoyskis Provincial Hospital in Tarnobrzeg, Szpitalna 1, 39-400 Tarnobrzeg, e-mail: gustaww@tlen.pl, phone: + 48158123001

Tables: 5 Figures: 0 References: 24 Full-text PDF www.hpc.edu.pl Copyright (C) Pope John Paul II State School of Higher Education in Biała Podlaska, Sidorska 95/97, 21-500 Biała Podlaska Indexation: Index Copernicus, AGR0, ProQuest, Polish Medical Bibliography, Polish Ministry of Science and Higher Education. This is an open-access article distributed under the terms of the Creative Common Attribution Non-commercial license (http://creativecommons.org/licenses/by-nc/3.0), which permits use, distribution and reproduction in any medium, provided the original works is properly cited, the use is non-commercial and is otherwise in compliance with the license.
} 
(Nemsadze et al. 2011, Carberry et al. 2013). The technique involves performing imaging studies on successive layers of the body in a plane transverse beam perpendicular to the long axis of the patient (Carberry et al. 2013).

\section{Objective}

The aim of the study was to attempt to assess the concentration of selected amino acids in plasma and correlating the results of laboratory tests with the occurrence of backaches.

\section{Materials and method}

The study involved 188 patients administering the cause of their symptoms as low back pain. The average age was 55.7. The group consisted of 107 women patients, whose average age was 56.9, while a group of men consisted of 81 patients, whose average age was 54.6 . Men accounted for $43 \%$ of respondents, while women accounted for $57 \%$ of the examined group of patients. All patients underwent diagnostic tests of lumbar spine-cross using multi-row spiral CT scanner Toschiba Aquilion 16 Radiologic evaluation of CT multiplanar reconstructions were performed in the MPR (Multi Planar Reconstruction). Depending on the diagnosis posed on the basis of imaging and clinical studies respondents were assigned to groups corresponding to the five disease units (Wójcik et al. 2013).

Clinical material for the study was collected from the blood of patients diagnosed with the pain of the lumbar spine. Plasma for the implementation of biochemical analysis was obtained from the blood collected into heparinized tubes from patients during the laboratory tests performed in computer tomography. Blood was collected from a vein in the arm in about 6 hours after breakfast. Free amino acid concentrations were determined by ion exchange chromatography using an automated amino acid analyzer AAA 400 from INGOS Praha. Determination of the concentrations of free amino acids in plasma was carried out at the Department of Medical Chemistry, Medical University of Lublin.

Amino acids were separated in a single column by column system of about $3 \mathrm{~mm}$ by $200 \mathrm{~mm}$, filled with ion exchanger resin Ostion LG FA. Five amino acids of lithium citrate buffer were used to separate, pH: 2.9, 3.1, 3.35, $4.05,4.90$. The eluted amino acids administered to a Teflon capillary reacted with the inflown ninhydrin to form colored compounds.

The separation of acidic and basic amino acids proceeded at 38-390C, while of the neutral amino acids ata temperature of 59-600C. The concentrations of the individual amino acids are given in micromoles per $1 \mathrm{~cm}^{3}$ of blood.

Determination of the concentrations of the individual amino acids in the blood plasma control group revealed its own standard for concentrations of individual amino acids.

Summarizes of the average concentrations of the individual amino acids and standard deviation of the control group patients were performed.

Tests were carried out after a favorable opinion of the Bioethics Committee, and subjected patients were informed about the purpose of the study and gave their written consent to participate in them.

The control group included 36 people aged 18 to 46 (average age 35.6).

The control group consisted of patients who underwent testing using computed tomography and there were no primary or secondary changes associated with degeneration in the lumbar spine.

\section{Results}

Patients, on the basis of research carried out by computed tomography, were divided into five groups. The first group (I) included patients diagnosed with osteoporosis. The second group (II) was composed of patients diagnosed with spondyloartrosis. The third group (III) was formed of the patients that had radicular syndrome. Patients with cancer and metastases to the bones of the spine formed the fourth (IV). Patients with vertebral fractures which occurred as a result of trauma formed the fifth (V). (tab1) (Sierakowski et al 2002).

Table 1. Characteristics of the groups of patients subjected to examination

\begin{tabular}{|c|c|}
\hline Group & Characteristics of the group \\
\hline I & Patients with osteoporosis \\
\hline II & Patients with spondyloartrosis \\
\hline III & Patients with radicular syndrome \\
\hline IV & Patients with cancer and metastases to the bones of the spine \\
\hline V & Patients with vertebral fractures which occurred as a result of trauma \\
\hline
\end{tabular}


The study included 188 patients from whom 33 patients were classified into a group with osteoporosis, 64 to a group of spondyloartrosis, 61 to a group of radicular syndrome, 14 to a group of cancer patients and exposed bone metastases, and 16 people to a group where due to an injury occurred fractures of the spine in the lumbarsacral (Table 2).

Table 2. Number of patients according to disease entities

\begin{tabular}{|c|c|c|c|c|c|}
\hline \multirow{2}{*}{} & \multicolumn{5}{|c|}{ GROUPS OF PATIENTS } \\
\cline { 2 - 6 } & I & II & III & IV & V \\
\hline (n) number of patients & 33 & 64 & 61 & 14 & 16 \\
\hline
\end{tabular}

Pawelski and Maj (Pawelski, Maj 1987) developed tables of normal levels of free amino acids in plasma. They conducted research on the Polish population. Their results were used to create a nationwide group. Comparisons were made of the nationwide group with the control group as well as with diseases: osteoporosis, spondyloartrosis, radicular syndrome, cancer of metastatic bone and spine injuries and fractures in the lumbarsacral paryt of spine.

On the basis of the analyzes it was shown that the concentration of methionine in the nationwide group and the control group was identical. In the nationwide group slightly higher concentrations were observed as compared to the control group in the case of arginine and glycine. Amino acids such as lysine, histidine, proline had a slightly higher concentration in the control group. The control group showed a significantly higher concentration in the case of aspartic acid, glutamic acid and taurine (Table 3).

Table 3. Comparison of concentrations of selected amino acids $(\mu \mathrm{mol} / \mathrm{cm} 3)$ in the tested nationwide and control group

\begin{tabular}{|c|c|c|c|c|}
\hline \multirow{2}{*}{ Amino acid } & \multicolumn{2}{|c|}{ Nationwide group } & \multicolumn{2}{c|}{ Control group } \\
\cline { 2 - 5 } & M & SD & M & SD \\
\hline lysine (LYS) & 0.186 & 0.005 & 0.199 & 0.040 \\
\hline histidine (HIS) & 0.080 & 0.005 & 0.090 & 0.013 \\
\hline arginine (ARG) & 0.085 & 0.008 & 0.073 & 0.068 \\
\hline aspartic acid (ASP) & 0.004 & 0.001 & 0.064 & 0.017 \\
\hline glutamic acid (GLU) & 0.050 & 0.001 & 0.175 & 0.084 \\
\hline metionine (MET) & 0.021 & 0.004 & 0.021 & 0.006 \\
\hline proline (PRO) & 0.185 & 0.003 & 0.195 & 0.063 \\
\hline taurine (TAU) & 0.060 & 0.005 & 0.148 & 0.038 \\
\hline glycine (GLY) & 0.280 & 0.007 & 0.268 & 0.071 \\
\hline
\end{tabular}

Analyzing the average concentration of essential amino acids in the plasma of patients of each group it has been found that it is higher in the case of lysine for each considered disease entity. Only average values of lysine in patients with cancer were slightly lower than in the control group. In contrast, the average concentration of methionine in all disease entities does not deviate from the average values in the control group (table 4).

When analyzing the average concentration of selected essential amino acids it has been shown that in the case of presented disorders their level underwent variation.

In osteoporosis, the average concentrations of all tested endogenous amino acids were higher than in the control group. Aspartic acid was an exception that in both groups showed similar values.

In spondyloartrosis the average concentrations of essential amino acids such as histidine, glycine and aspartic acid showed no fluctuations in comparison to the control group, whereas in the case of amino acids such as arginine, proline and glutamic acid higher values than those obtained in the control group were found. Only in the case of taurine concentrations were lower than in the control group.

In radicular syndrome average concentrations of all tested endogenous amino acids: histidine, arginine, glycine, proline, taurine, aspartic acid and glutamic acid were significantly higher than the average concentrations of endogenous amino acid in the control group.

In cancer the average concentrations of histidine, glycine, proline, taurine, aspartic acid and glutamic acid had lower values than in the control group. Only arginine was characterized by a higher concentration compared to the control group. 
Table 4. Comparison of concentrations of selected amino acids $(\mu \mathrm{mol} / \mathrm{cm} 3)$ in disease units

\begin{tabular}{|c|c|c|c|c|c|c|c|c|c|c|}
\hline \multirow{2}{*}{ Amino acid } & \multicolumn{2}{|c|}{ Osteoporosis } & \multicolumn{2}{|c|}{ Spondyloartrosis } & \multicolumn{2}{c|}{$\begin{array}{c}\text { Radicular } \\
\text { syndrome }\end{array}$} & \multicolumn{3}{|c|}{ Cancer } & \multicolumn{2}{|c|}{$\begin{array}{c}\text { Injuries and } \\
\text { fractures }\end{array}$} \\
\cline { 2 - 12 } & $\mathbf{M}$ & SD & M & SD & M & SD & M & SD & M & SD \\
\hline Lizyna & 0.231 & 0.050 & 0.213 & 0.057 & 0.268 & 0.082 & 0.191 & 0.080 & 0.214 & 0.068 \\
\hline methionine & 0.023 & 0.007 & 0.021 & 0.006 & 0.028 & 0.008 & 0.019 & 0.007 & 0.020 & 0.008 \\
\hline histidine & 0.096 & 0.029 & 0.093 & 0.022 & 0.112 & 0.025 & 0.071 & 0.026 & 0.089 & 0.027 \\
\hline arginine & 0.130 & 0.119 & 0.125 & 0.111 & 0.171 & 0.171 & 0.114 & 0.183 & 0.148 & 0.116 \\
\hline glycine & 0.327 & 0.107 & 0.261 & 0.072 & 0.373 & 0.084 & 0.246 & 0.119 & 0.290 & 0.103 \\
\hline proline & 0.272 & 0.114 & 0.241 & 0.079 & 0.292 & 0.090 & 0.183 & 0.052 & 0.250 & 0.114 \\
\hline taurine & 0.160 & 0.040 & 0.139 & 0.047 & 0.175 & 0.069 & 0.144 & 0.069 & 0.146 & 0.056 \\
\hline aspartic acid & 0.067 & 0.026 & 0.063 & 0.016 & 0.080 & 0.035 & 0.055 & 0.026 & 0.062 & 0.038 \\
\hline glutamic acid & 0.259 & 0.127 & 0.199 & 0.101 & 0.275 & 0.147 & 0.158 & 0.078 & 0.259 & 0.141 \\
\hline
\end{tabular}

In the group of injuries and fractures the average concentrations of histidine, aspartic acid and taurine correspond to average concentrations in the control group. Average concentrations of arginine, glycine, proline and glutamic acid showed higher values than in the control group (table 4).

Using the Student's t-test, a comparison of concentrations of free amino acids in the blood plasma of patients in the various disease entities was made.

Comparison of the concentration of free amino acids in the blood plasma of patients in the control group with the concentration of free amino acids in the blood plasma of healthy subjects (nationwide group) showed significantly higher values for taurine, histidine, aspartic acid and glutamic acid.

Average concentrations of selected amino acids have proven to be very similar in both groups. Slightly higher values proved to be in the control group for proline and lysine. In one case involving arginine higher concentrations of this amino acid were in the nationwide group (table 5).

Table 5. Concentrations of free amino acids $(\mu \mathrm{mol} / \mathrm{cm} 3)$ in the nationwide and in the control group

\begin{tabular}{|c|c|c|c|}
\hline \multirow{2}{*}{ Amino acid } & \multicolumn{2}{|c|}{ TESTED GROUPS } & \multirow{2}{*}{$\begin{array}{l}\text { STATISTICAL } \\
\text { SIGNIFICANCE }\end{array}$} \\
\hline & NATIONWIDE & CONTROL & \\
\hline PROLINE & $0.185 \pm 0.003$ & $0.195 \pm 0.063$ & ns \\
\hline TAURINE & $0.060 \pm 0.005$ & $0.148 \pm 0.038$ & 0.05 \\
\hline LYSINE & $0.186 \pm 0.005$ & $0.199 \pm 0.040$ & ns \\
\hline METIONINE & $0.021 \pm 0.004$ & $0.021 \pm 0.006$ & ns \\
\hline ARGININE & $0.085 \pm 0.008$ & $0.073 \pm 0.068$ & ns \\
\hline GLYCINE & $0.280 \pm 0.007$ & $0.268 \pm 0.071$ & ns \\
\hline HISTIDINE & $0.080 \pm 0.005$ & $0.090 \pm 0.013$ & 0.05 \\
\hline ASPARTIC ACID & $0.004 \pm 0.001$ & $0.064 \pm 0.017$ & 0.05 \\
\hline GLUTAMIC ACID & $0.050 \pm 0.010$ & $0.175 \pm 0.084$ & 0.05 \\
\hline
\end{tabular}

\section{Discussion}

Back pain syndrome is one of the most common health problems associated with ailments within the human locomotor system. Because of its prevalence, it was classified as a disease of civilization. According to many researchers, back pain affects not only the elderly but also young people, manifesting its beginning even at the age of 20 (Borenstein 2013).

The most common reason for the occurrence of complaints from the spine are overloads and lack of adequate physical activity weakening all the elements of the locomotor system. Movement and stillness affect the rate of biochemical changes occurring in every living organism. All proteins which are essential in building blocks of cellular structures wear out and degrade (Umulis, Othmer 2013).

It would seem that a passive organ motion is mainly bones having little in common with proteins, but it is often forgotten that it is the protein that form a network of collagen binding in the minerals responsible for bone density. With age there is a disturbance between the processes of synthesis and protein breakdown. In young individuals dominate the processes of biosynthesis, biodegradation processes in the elderly, while in the middle the two processes are in balance (Fratzl-Zelman et al. 2013).

Spinal disorders affect the functioning of the whole organism. They can have an effect on the metabolism of proteins, and especially on changes in the concentration of free amino acids in the blood (Mathieson et al 2013). 
Maintaining normal levels of serum amino acids depends on the balance between AA supplied and used by the body. Each disease causes disruption of homeostasis of the organism to varying degrees. Structural disorders of the lumbar spine also affect the functioning of the whole organism. Determination and comparison of the concentrations of free AA in the blood plasma of patients with osteoporosis, spondyloartrosis, radicular syndrome, bone tumors and patients with spinal injuries and fractures was the subject of this work.

The study included 188 patients examined by computed tomography due to back pain in the lumbar-sacral part of spine. Their average age was 55 .

The study found significant differences in the concentrations of amino acids in the studied disease entities.

Studies of plasma amino acid concentrations showed that extending back pain with degeneration of bone segments and soft tissue are characterized by increased levels of all amino acids tested. A different result gave the research conducted on a group of patients with cancer, in which cancer metastases to the bones of the spine were determined. In this group, as in the only one, there was recorded a significant decrease in the level of all tested amino acids compared to the control group.

In the course of many diseases, there is a varying extent of the use of a pool of free amino acids. The concentrations of free amino acids in the blood plasma are the basis for determining the homeostasis of the organism. Transfers concentrations of free amino acids in the blood may serve as a prognostic indicator in assessing the severity of osteoarthritis (Fratzl-Zelman et al 2013).

Amino acids which are neurotransmitters, such as glutamic acid (Glu), aspartic acid (Asp), taurine (Tau), and glycine (Gly) are widely distributed in biological fluids and tissues and have important physiological functions, such that the evaluation of their concentration in the body plays an important role in physiology (Zinellu et al 2013).

Glutamic acid is an important neurotransmitter that is the compound that allows conduction of nerve impulses. Its main task is to stimulate action in the cerebral cortex of mammals.

The transformation of normal cells into cancer is associated with changes in the concentrations of amino acids (Inbar et al. 1971).

Ibrachim et al conducted studies in mice by injecting them benzopyrene to induce lung cancer, then the mice were dosed mixtures containing vitamins and amino acids such as lysine and proline. In its conclusions, he reported that mixtures are protective with the ability to suppress cancerous changes and allow you to restore normal biochemical and histopathological parameters (Ibrachim et al 2013).

Research shows that mixtures with proline and lysine have a protective effect and may contribute to the improvement of the final therapeutic effect.

Reducing the concentration of proline and lysine was observed in our study in the case of metastases of the bone. This may indicate the compound concentration shifts / AA in the direction of deficiency in the case of developing cancer. Neoplastic disease appears to be a factor in reducing the biosynthesis in the living body.

Lysine is overexpressed in many tumor types including ovarian cancer that has metastases to the bone (Konovalov, Garcia-Bassets 2013).

Carregaro et al reported that small proline-rich proteins may be associated with increased proliferation of tissues in the case of tumor processes. However, their role in the pathophysiological processes remains unclear, which requires further research (Carregaro et al. 2013).

Intracellular free amino acids are involved in the regulation of metabolic pathways and control the build up of muscle proteins. Depletion of intracellular content of amino acids such as arginine or glutamine reduction can affect and cause their activation neuromotoric disorders (Sales et al. 2013).

In humans and other mammals, endogenous glucocorticoids are necessary to adapt to physiological stress. However, when the concentration of glucocorticoids is increased for a long period of time, the central nervous system is predisposed to the development of disorders and neurological diseases formation. Canteros in his work shows that arginine may counteract the neurotoxic effects of glucocorticoids (Canteros 2013).

Similar findings are presented by Dorniak-Wall et al and they pay attention to the neuroprotective effect of arginine for neural tissue (Dorniak-Wall et al. 2013).

Rai and Penn emphasize the importance of proline in defensive reactions to the stress of living organisms. This has a tangible meaning when considering back pain in terms of suffering, both physical and mental. Increasing the concentration of proline can play in this case a protective role (Rai, Penna 2013).

Taurine has a substantial effect on the proliferation of inflammatory cells resulting in reduced concentrations of histamine. It also has a significant impact on the processes associated with the formation of collagen. Taurine influences the strength of the soft tissues by increasing their resistance to noxious agents (Dinçer et al. 1996).

Taurine is found in high concentrations in bone cells enhancing bone formation and inhibiting its loss. Osteoporosis is a disease associated with increased bone stiffness is characterized by a thinning of traffic camera stabilizing structure whereby even the low-energy injuries cause significant damage. The concentration 
of taurine in the case of osteoporosis is higher than normal, however, metabolic incorporation prevent building of the collagen in so-called bone matrix (D’Eufemia et al. 2010).

Methionine s heavily involved in the processes of cartilage formation, but in the case of the increasing changes associated with the spondyloarthropathy reduction in the concentration of this amino acid is observed (Vijayan et al. 2013).

\section{Conclusion}

1. The concentration of amino acids varies with the severity of degenerative changes in the joints and intervertebral discs.

2. In osteoporosis and radicular syndrome occurs the growth of all the tested concentrations of amino acids and cancer decrease in the concentrations of all tested amino acids.

3. The highest increase in the concentrations of all tested amino acids is present i radicular syndrome.

\section{References:}

1. Borenstein D. (2013), Mechanical low back pain-a rheumatologist's view. Nat Rev Rheumatol. 9(11), p. 643-53.

2. Brox J.I., Storheim K., Grotle M., Tveito T.H., Indahl A., Eriksen H.R. (2008), Evidence-informed management of chronic low back pain with back school, brief education and fear-avoidance training. The Spine Journal; 8: p. 28-39.

3. Canteros MG. (2013), D-arginine as a neuroprotective amino acid: promising outcomes for neurological diseases. Drug Discov Today. 16, p. 359-364.

4. Carberry G.A., Pooler B.D., Binkley N., Lauder T.B., Bruce R.J., Pickhardt P.J. (2013), Unreported vertebral body compression fractures at abdominal multidetector CT. Radiology. 268(1), p. 120-6.

5. Carregaro F., Stefanini A.C., Henrique T., Tajara E.H. (2013) Study of small proline - rich proteins (SPRRs) in health and disease: a review of the literature. Arch Dermatol Res., 305 (10), p. 37-42.

6. Ciejka E., Wójtowicz K. (2009), Ocena skuteczności stosowanych zabiegów fizjoterapeutycznych w leczeniu choroby zwyrodnieniowo-wytwórczej stawów obwodowych i kręgosłupa, Balneol Pol, 3(117) p. 189-193.

7. D’Eufemia P., Finocchiaro R., Celli M., Raccio I., Zambrano A., Tetti M., Smacchia P., Iacobini M. (2010), Taurine deficiency in thalassemia major-induced osteoporosis treated with neridronate. Biomed Pharmacother. 64(4), p. 271-4.

8. Dinçer S., Babül A., Erdoğan D., Ozoğul C., Dinçer S.L. (1996), Effect of taurine on wound healing. Amino Acids, $10(1)$, p. 59-71.

9. Dorniak-Wall T., Grivell R.M., Dekker G.A., Hague W., Dodd J.M. (2013), The role of L-arginine in the prevention and treatment of pre-eclampsia: a systematic review of randomised trials. J Hum Hypertens., 28 (4), p. $31-35$.

10. Fratzl-Zelman N., Schmidt I., Roschger P., Glorieux F.H., Klaushofer K., Fratzl P., Rauch F., Wagermaier W. (2013), Mineral particle size in children with osteogenesis imperfecta type I is not increased independently of specific collagen mutations. Bone, (13), p. 485-7.

11. Ibrachim A.M., Borai I.H., Ali M.M., Ghanem H.M., Hegazi Ael-S., Mousa A.M. (2013), Inhibitory effect of a mixture containing vitamin $C$, lusine, proline, epigallocatechin gallate, zinc and alpha-1-antitrypsin on lung carcinogenesis induced by benzo(a) pyrene in mice. J Res Med Sci, 18(5), p. 427-34.

12. Inbar M., Ben-Bassat H., Sachs L. (1971), Location of amino acid and carbohydrate transport sites in the surface membrane of normal and transformed mammalian cells. J Membr Biol, 6(3), p. 195-209.

13. Konovalov S., Garcia-Bassets I. (2013), Analysis of the levels of lysine-specific demethylase 1 (LSD1) mRNA in human ovarian tumors and the effects of chemical LSD1 inhibitors in ovarian cancer cell lines. J Ovarian Res, $6(1)$, p. 75.

14. Mathieson S., Maher C.G., McLachlan A.J., Latimer J., Koes B.W., Hancock M.J., Harris I., Day R.O., Pik J., Jan S., Billot L., Lin C.W. (2013), PRECISE - pregabalin in addition to usual care for sciatica: study protocol for a randomised controlled trial. Trials, 14, p. 213.

15. Nemsadze G., Lapiashvili E., Urushadze O., Gotsadze G. (2011), Role of multislice spiral computed tomography in diagnosis of spinal injuries in polytrauma patients. Georgian Med News, 11(200), p. 42-51.

16. Pawelski S., Maj S. (1987), Normy i kliniczna interpretacja badań diagnostycznych w medycynie wewnętrznej. PZWL.

17. Rai AN., Penna S. (2013), Molecular evolution of plant P5CS gene involved in proline biosynthesis. Mol Biol Rep, 40(11), p. 6429-35.

18. Sales F., Pacheco D., Blair H., Kenyon P., McCoard S. (2013), Muscle free amino acid profiles are related to differences in skeletal muscle growth between single and twin ovine fetuses near term. Springerplus, 2, p. 483.

19. Sierakowski S., Mika J., Klimiuk P.A., Lewandowski B., Kita K., Muklewicz E. (2002), Zasady postępowania diagnostycznego w chorobie zwyrodnieniowej stawów. Nowa Medycyna, 115(2), p. 4-6. 
20. Umulis DM., Othmer HG. (2013,) Mechanisms of scaling in pattern formation. Development, 140(24), p. 4830-43. 21. Vijayan V., Khandelwal M., Manglani K., Gupta S., Surolia A. (2013), Methionine Downregulates TLR-4/MyD88/ NF- $\kappa$ B Signaling in Osteoclasts Precursors to Reduce Bone Loss during Osteoporosis. Br J Pharmacol, 30, p. 434-7.

22. Wójcik G., Bulikowski W., Piskorz J., Stawińska T., Sokołowska B. (2013), Computed tomography and stretch tests in diagnosing sciatica as a method for ensuring patient well-being. In: Health and wellness. W. Kurlej (ed.), Lublin, NeuroCentrum, p. 223-235

23. Zinellu A., Sotgia S., Deiana L., Carru C. (2013), Analysis of neurotransmiter amino acids by CE-LIF detection in biological fluids. Methods Mol Biol, 919, p. 35-42.

Submitted: 03.04.2015

Accepted: 13.07.2015 